\title{
日本語版道徳基盤尺度の妥当性の検証 イデオロギーとの関係を通して—
}

\section{村山 綾 近畿大学 三浦 麻子 ${ }^{2}$ 関西学院大学}

\author{
Validation of the Japanese Version of the Moral Foundation Questionnaire: \\ Investigating the relationship with ideologies
}

Aya Murayama (Kindai University) and Asako Miura (Kwansei Gakuin University)

\begin{abstract}
The purpose of this study was to investigate the validity of the Japanese version (Kanai, 2013) of the Moral Foundation Questionnaire (MFQ; Graham, Nosek, Haidt, Iyer, Koleva, \& Ditto, 2011). In Study 1, we tested the internal validity of the MFQ using data collected from 855 participants, following the procedure by Graham et al. (2011). Analyses revealed that the five-factor model showed the best fit among any other model. In addition, a higher score in In-group, Authority, and Purity was related weakly but significantly to conservative political identity. In Study 2, we tested test-retest reliability as well as the relationships between the MFQ and ideologies, using data collected from 470 participants. The test-retest reliability was relatively low, compared to Graham et al. (2011). The relationships between the MFQ and ideologies were consistent overall with the Moral Foundations Theory. However, we also found several inconsistent results such as a higher score in Purity resulting in agreeing more with a liberal opinion. Usage of the Japanese version of the MFQ in empirical studies was discussed.
\end{abstract}

Key words: Moral Foundation Theory, Moral Foundation Questionnaire, ideology.

The Japanese Journal of Psychology

2019, Vol. 90, No. 2, pp. 156-166

J-STAGE Advanced published date: May 20, 2019, https://doi.org/10.4992/jjpsy.90.17234

本研究の目的は, 善悪の判断に際して, 5 つの道徳 基盤に個人がどの程度依拠しているかを測定する道徳 基盤尺度（Moral Foundation Questionnaire（以下，MFQ とする）：Graham et al., 2011）の日本語版（金井, 2013）を用いて，日本国内に扔ける尺度の妥当性の検 証を行うことである。

道徳に関する初期の研究は, Piaget（1965）や Kohlberg（1968）によって, 主に発達心理学分野で検 討されてきた。具体的には, 発達段階が進むに従って, 正義や公正さに関わる要素（人を傷つけない，個人の 権利を侵害しないなど）が洗練されていくという議論

\footnotetext{
Correspondence concerning this article should be sent to: Aya Murayama, Faculty of International Studies, Kindai University, Kowakae, Higashiosaka 577-8502, Japan. (E-mail: murayama@intl.kindai.ac.jp) 本研究は, 関西学院大学「人を対象とした臨床・調査・実 験倫理委員会」の規定に基づき実施の許可を得た（受付番号 : 2015-45)

2 現所属 : 大阪大学大学院人間科学研究科
}

が中心であった。その後, 文化人類学的研究 (Shweder \& Haidt, 1993) p社会心理学的研究 (Haidt, Koller, \& Dias, 1993）によって，正義や公正さに偏りすぎた道 徳研究は主に欧米のような個人が主体となった社会の みに適用しうるものであって, 集団やコミュニティを 重視する他の文化には当てはまらないという指摘がな された。加えて，人を物理的に傷つけることがなく， 個人の権利を侵害することもない事案（例えば, 自国 の国旗を必要ないからといって雑巾にする, 飼い犬の 肉を食べるなど）に対しても，人は道德的に間違って いると判断することも示された。このように，異なる 専門分野の研究者によって道徳研究が進められていく 中で，人の道徳心にこれまで考えられてきたものより も直観的かつ複雑な構造が想定されるようになった。 道徳基盤理論は, こうした複雑な構造を扱うために Haidt \& Joseph $(2004,2007)$ が提唱した理論である。非 欧米圈で重視される価値観にも言及した Shweder, Much, Mahapatra, \& Park (1997) による, 自律性 (autonomy), コミュニティ (community), 神聖さ (divinity) からな 
る3つの倫理基準に多大な影響を受けている。自律性 は，主に欧米の価值基準が反映されており，人を傷つ けないことや個人の権利を侵害しないことに関わる側 面である。一方コミュニティには，非欧米文化圈の価 值基準が反映されており，義務や階層，相互依存的な 関係性に関わる側面が含まれる。神聖さは，伝統，高 潔さ，自然や神を冒涜しないことに関わる側面を含む。 非欧米諸国で重視される倫理基準を扱おうとした点 や，宗教的な教えや自然の摂理のような，神との関係 性において生じる倫理基準も含む点が, 発達心理学的 視点から正義や公正さのみを扱った Piaget（1965）や Kohlberg（1968）の理論とは大きく異なる。文化人類 学的な視点に進化論に基づく説明を導入し, 自律性と コミュニティに関わる倫理基準をさらに細分化して, 5 つの道德基盤が想定された。

5 つの道徳基盤は，以下のように説明される。(a) 他者に苦悩を強いることを非難し, 同情と保護を与え ることを徳とする Harm/care（H)，（b）不公平な扱い を認めず，互恵性と正義を徳とする Fairness/reciprocity (F), (c) 裏切り行為を警戒し, 集団への忠誠と義務 の遂行を徳とする Ingroup/royalty（I），（d）権威に対 する服従や階層的な関係性, 社会秩序を尊重すること を徳とする Authority/respect (A)，（e）身体的，精神 的污染を忌避し, 潔癖さや貞節を守ることを徳とする Purity/sanctity（P)，である。そして，すべての人にこ れらの基盤が味覚受容器のように備わっており, 文化 や社会によってどの基盤を重視するかが異なるとされ ている（Haidt, 2012; Haidt \& Joseph, 2004, 2007）。

Haidt らによる道徳基盤理論の 1 つの特徵は, 道徳 基盤とイデオロギーとの関連を示した点にある (Graham, Haidt, \& Nosek, 2009; Haidt \& Graham, 2007; Haidt, Graham, \& Joseph, 2009)。彼らは, 中絶, 同性婚, 死刑制度のような，政治の場で扱われる議論の多くに $5 つ の$ 道徳基盤が関わっており，これらの問題に対す る, 時に嬂烈な意見の不一致が, 各道徳基盤を重視す る程度の違いによって生じる可能性を指摘した。そし て, 政治的立場がリベラル（個人の自由を尊重し, 個 人的な成長や成功を追い求める立場）の場合は H と F のみを, 保守（伝統や権威を重んじ，人として正しく 生きるためには一定の制約が必要であると考える立 場）の場合は 5 つすべての基盤を，人が持つべき倫理 基準として重視することを示した (Graham et al., 2009)。道徳とイデオロギーとの関係を社会心理学的 な視点から明らかにしようとするこれらの試みは, イ

その後, Iyer, Koleva, Graham, Ditto, \& Haidt (2012) や, Haidt （2012）によって，自由に対する関心 (Liberty) に関わる基盤が 追加された 6 基盤に関する検討もあるが, 本研究では先行研究 の知見が多く, http://www.moralfoundation.org/で配布されている 5 基盤に基づく尺度に関わる議論を対象に検討する。
デオロギーに基づく人々の対立の原因を説明しうるも のとして注目されている（Haidt, 2012）。

なお,こうした道徳に関する心理学研究の経緯は唐 沢（2013）によるレビューにも詳しい。

\section{道徳基盤の測定に関する先行研究と問題点}

個人が各道徳基盤を重視する程度を測定する方法と して，これまでに自己報告式の尺度，潜在指標，生理 心理または神経科学的指標，テキスト分析などが提案 されてきた（Graham et al., 2011）。中でも自己報告式 の尺度は, 研究者や参加者にとって, 簡便に多くのデー 夕が収集でき，文化間比較を行いやすいため多くの研 究で利用されている。政治的立場と道徳基盤との関連 を示した Graham et al.（2009）で用いられていた自己 報告式の尺度を土台として作成されたのが MFQ (Graham et al., 2011) である。MFQ は, 善悪判断を行 う際の判断材料として各基盤が関連する強さを測定す る 15 項目（関連度：relevance）と, 各基盤と関連す る意見や主張にどの程度同意するかを判断させる 15 項目 (判断 : judgement), ダミー 2 項目の計 32 項目 で構成される。尺度構成の特徵としては，(a) 複数の 観点（「関連度」と「判断」）から評価を求める質問項 目を用意したこと，(b) 抽象的な評価を求める「関連 度」項目を補足する意味も含め, 道徳基盤を実際の判 断に用いるかどうかを測定する「判断」項目を設定し たこと，(c) 類似した項目のみを用いて内的一貫性を 高めるというよりは, 内的一貫性が低くなったとして も, 幅広い場面での道徳判断を対象として項目を作成 していること，が挙げられる (Graham et al., 2011)。 この研究では, インターネット上で収集したデータ ( = 34,476）を対象に, 1 因子モデル（H, F, I, A, Pすべ てを含むもの), 2 因子モデル（H, F を個人の権利と 繁栄に関わる道德基盤である「個人志向 (Individualizing)」，I，A，Pを役割や義務を通して個人 を結びつけることで集団や組織の強度を増していくた めの道徳基盤である「連帯志向 (Binding)」としてま とめるもの), 3 因子モデル（2因子モデルから P を 独立させたもの), 階層モデル（H, F の上位概念とし て「個人志向」を, I, A, P の上位概念として「連帯志 向」を想定したもの) と, 5 因子モデルの比較を行った。 そして, 最終的に 5 因子モデルの適合度が相対的に高 く, 各因子の $\alpha$ 係数も比較的高くなることを示した。 また, 回答者を世界各国から募集して東洋と西洋の回 答傾向の差についても検討しており， I と P の得点は 西洋よりも東洋で高いことが示された。地域ごとの検 討を通して，5つの道徳基盤そのものは文化を超えて 存在しており，文化によって重視される度合いが異な るとする道徳基盤理論と一貫する結果が得られたとさ れている。

大規模調査から MFQ における 5 因子モデルの妥当 
性と信頼性を確認した Graham et al.（2011）の結果は 貴重ではあるが，大きな課題として，調査言語が英語 に限られていたことによるセレクションバイアスが挙 げられる。回答者は様々な文化圈に属してはいるが, 英語を理解し，西洋の文化や環境に触れた経験が多い ものであったと考えられる。そのため, MFQ が文化 普遍的で，すべての人が 5 つの道徳基盤を持ち合わせ ているという Haidt らの主張を十分に検討できている のかというと疑問が残る。実際, MFQの多言語化プ ロジェクト (http://www.moralfoundations.org/より参照 可能）によって，様々な言語を用いた妥当性の検討が 世界各国で行われ始めたが，5因子モデルを支持しな い結果も示されている。スウェーデン語版を用いて妥 当性を検討した Nilsson \& Erlandsson（2015）では，他 のモデルよりも5 因子モデルの方が適合度は高かった が，オリジナル版ほどではなく，階層モデルとの間に も統計的に有意な差はなかった。ニュージーランドで 行われた研究（Davies, Sibley, \& Liu, 2014）でも，同 様に階層モデルと 5 因子モデルとの間に適合度の大き な違いはみられなかった。加えて, 関連度のみの項目 を用いた場合に，すべての項目を用いた場合よりも5 因子モデルの当てはまりが良いことも示された。非欧 米圈であるトルコでの検討では， 5 因子モデルの当て はまりが相対的に良いが, 個人志向と連帯志向に基づ く議論の方が妥当な場合もあるとの提案がなされてい る (Yilmaz, Harma, Bahcekapili, \& Cesur, 2016)。ドイ ツ語版を用いた Bowman（2010）の検討では， 5 因子 モデルの適合度が低く, 個人志向, 連帯志向で構成さ れる高次の 2 因子が有意な正の相関関係 $(r=.23)$ を 示した。この結果は, 両者は無相関であるとする Graham et al. (2011) の結果と一致しない。そこで Bowman（2010）は，適合度指標をもとにモデルを修 正し，連帯志向の下位因子から I を除外すると両者の 有意な正の相関関係がなくなり $(r=.17)$, 相対的な 妥当性も高いとの結論に至った。Kim, Kang, \& Yun （2012）によるハングル版の検証では，5因子モデル の適合度も $\alpha$ 係数も低く, H, F を個人志向, I, A を連 帯志向として項目をまとめる方が $\alpha$ 係数が高くなっ た。このように，世界各国で実施されている MFQの 妥当性の研究結果は一貫していない。

日本国内では, 一部の項目を用いた妥当性の検証や, 日本語版 MFQ（Kanai, 2012; 金井, 2013）を利用した 研究報告が単発的になされているが，5因子モデルの 妥当性に疑問が残る結果が示されている。小杉(2013) は, MFQの土台となった Graham et al.（2009）の尺 度（30 項目）の日本語版を作成し, 日本人大学生を 対象に検討を行った。その結果, 理論的背景から 5 因 子モデルを採用している。ただし，第 1 ，第 2 因子に は複数の基盤に関する項目が混在しており, 先行研究 で検討されたモデルと一致しない。坂本・野波・大友・
田代（2014）は， 日本語版 MFQ（金井, 2013）を用 いて道徳基盤と公共政策をめぐる権利の正当性判断の 関連を検討している。各基盤の $\alpha$ 係数は全体的にあま り高くなく，特に P を構成する項目では非常に低い 值（.46）だった。MFQが多くの言語に翻訳され，多 文化に扔ける比較がしやすい状況において，日本語版 MFQ（金井, 2013）の妥当性，信頼性の検証を行う必 要性は非常に高いと考えられる。

以上の背景から, 本研究では日本語版 MFQ（金井, 2013）を用いて, Graham et al. (2011) で示されたモ デルとの比較および，イデオロギーとの関連の検討を 通してその妥当性と信頼性を検証する。同様の目的で 実施された先行研究の多くでは, 因子構造の確認と, 回答者の政治的立場に関わる項目と各道徳基盤得点と の相関関係を明らかにする分析が行われている（Kim et al., 2012; Nilsson \& Erlandsson, 2015)。本研究では 2 つの研究から, 日本語版 MFQ の妥当性と信頼性の検 証を行う。研究 1 では, 日本語版 MFQへの回答を求め, その因子構造や，イデオロギーとの関連を検討する。 Haidt の道徳基盤理論に従うと, 政治的立場がリベラ ルよりも保守の方がI, A, P の得点が高いと予測され る。また, Nilsson \& Erlandsson（2015）では, H, F の 得点と,リベラル的なイデオロギーである「平等な社 会システムを選好する傾向 (Preference for equality)」, および，I，A，Pの得点と，保守的なイデオロギーであ る「現状の社会システムを維持することを望む傾向 (Resistance to Change)」との間に正の相関が示されて いる。この結果についても，再現性を検討する。

続く研究 2 では, 研究 1 の参加者に再度参加を求め, MFQ の再検査信頼性を検討する。加えて, イデオロ ギーに関わる 3 つのシナリオから, 道徳基盤との関連 をより詳細に検討する。

\section{研 究 1}

\section{方 法}

参加者 2017 年 6 月に, クラウドソーシングサー ビス（株式会社クラウドワークス）の登録者（18 歳 以上の男女 1,018 名）に対して, オンラインアンケー トシステム Qualtrics 上で作成された調査票にアクセ ス, 回答を求めた。すべての設問に回答した者に, ク ラウドワークスを経由して 50 円の報酬を支払った。 その中で, 継続調査への参加に同意し, かつ回答選択 肢を指示する 2 項目（Directed Questions Scale（以下， DQS とする) : 例「この項目は「5. 極めて関係がある」 を選択してください」, 三浦・小林, 2016）に正答した 855 名（男性 306 名, 女性 549 名), 平均年齢 35.63 歳 $(S D=9.82)$ を分析対象とした。

手続き 参加者はまずMFQに回答し，その後続く 質問項目に回答した。 
Table 1

Internal Relations between Relevance and Judgement Subscales for the Japanese MFQ

\begin{tabular}{|c|c|c|c|c|c|}
\hline & \multicolumn{5}{|c|}{ MFQ relevance subscales } \\
\hline & $\begin{array}{c}\text { Harm } \\
(\alpha=.76)\end{array}$ & $\begin{array}{l}\text { Fairness } \\
(\alpha=.68)\end{array}$ & $\begin{array}{l}\text { Ingroup } \\
(\alpha=.58)\end{array}$ & $\begin{array}{l}\text { Authority } \\
(\alpha=.53)\end{array}$ & $\begin{array}{c}\text { Purity } \\
(\alpha=.50)\end{array}$ \\
\hline \multicolumn{6}{|c|}{ MFQ judgement subscales } \\
\hline $\operatorname{Harm}(\alpha=.50)$ & .35 & .25 & .19 & .19 & .29 \\
\hline Fairness $(\alpha=.43)$ & .33 & .30 & .27 & .24 & .27 \\
\hline Ingroup $(\alpha=.30)$ & .16 & .14 & .33 & .30 & .19 \\
\hline Authority $(\alpha=.31)$ & .06 & .05 & .34 & .36 & .19 \\
\hline Purity $(\alpha=.39)$ & .22 & .21 & .30 & .30 & .31 \\
\hline \multicolumn{6}{|c|}{ After partialing political ideology } \\
\hline Harm & .35 & .25 & .18 & .19 & .29 \\
\hline Fairness & .33 & .30 & .28 & .25 & .27 \\
\hline Ingroup & .16 & .15 & .31 & .28 & .18 \\
\hline Authority & .05 & .06 & .31 & .33 & .18 \\
\hline Purity & .22 & .22 & .28 & .28 & .31 \\
\hline
\end{tabular}

Note. The highest correlation in each row is indicated in bold.

測定項目 （a）金井（2013） ${ }^{4}$ による日本語版 MFQ (「関連度」の 15 項目については，0：まったく関係が ないー5：極めて関係がある,「判断」の 15 項目につ いては， 0 :まったく同意しない一 5 : 非常に同意する) に回答を求めた 5 。（b）イデオロギーについて, 3 種類 の変数を測定した。まず「平等への選好」は，国家間 の富の平等さに関わる 2 項目（「裕福な国は, 他の貧 しい国々に自分たちの富を分配する道德的義務を負っ ている」，「経済的，社会的に弱い立場にある発展途上 国の人々の貧困を軽隇する目的のフェア・トレード(公 平な貿易）は，支持されるべきだ」，0：まったく同意 できない一 6 : 非常に同意できる， $\alpha=.66 ）$ を作成した。 その際, Nilsson \& Erlandsson（2015）で用いられた 15 項目からなる尺度を参考にした。次に「変化への抵抗」 を 2 項目（「私は, どのような形であれ，今の社会秩 序を大きく変えることには消極的だ」,「現状の社会シ ステムに問題があったとしても, 社会の安定が維持さ れた方がよい」，0：まったく同意できないー6：非常 に同意できる， $\alpha=69$; Jost et al. (2007) の研究 3 で使 用された項目)で測定した。最後に政治的立場 (Political

\footnotetext{
4 金井（2013）の日本語版を土台として, 尺度の妥当性・信 頼性の検討を行うことについて，著者より了承を得た。

5 日本語版 MFQ（金井, 2013）のより良い翻訳可能性を探索 的に検討した村山・三浦（2017）は, 金井（2013）に特に大き な問題がないことを指摘している。この結果を踏まえ, 本研究 では項目 30 に使用されている「貞節」および「自然の摂理」の 意味のみを補足し，金井（2013）による設問文と項目をそのま ま使用した。
}

identity）について，リベラル（0）一保守（10）,「わ からない」で測定した。

\section{結果と考察}

妥当性に関する検討 まず, Graham et al. (2011) の分析手続きに従い,「関連度」と「判断」の下位尺 度ごとに道徳基盤得点を算出し, 相関係数を算出した。 その際，政治的立場を統制変数とした偏相関係数も算 出した（Table 1)。「関連度」と「判断」の両方で, 同 一基盤間に中程度の正の相関関係がみられた。ただし， 他基盤との相関係数の差は Graham et al. (2011) より は小さかった。また， $\mathrm{F}$ は同一基盤間ではなく， Hの 下位尺度との相関の方が強かった。なお, Graham et al. (2011) では, 個人志向に関連する H, F と, 連帯志 向に関連する I, A, P の間には相関関係がみられない ことが示されている。しかし本研究では, F と P が, 他のすべての基盤と.20 以上の正の相関を示した。ま た「判断」で測定している各基盤の $\alpha$ 係数は特に低い 值を示した $(\alpha=.30-.50)$ 。

続いて, Graham et al. (2011) と同様に, すべての 項目を用いた探索的因子分析（最尤法, プロマックス 回転）を行った結果，ガットマン基準に基づき 7 因子 が抽出された 6 。これは, 6 因子が抽出された Graham et al. (2011) の結果と異なる。固有值の值, Haidt（2012） の理論に基づく解釈可能性, H, F と I, A, P で構成さ れる 2 因子構造が検討された Graham et al. (2011) の

\footnotetext{
6 因子分析の結果を電子付録に掲載した。
} 
結果との比較可能性を踏まえ, 因子数を 2 に指定して 再度分析を行った。その結果, 「関連度」では H, F, 「判 断」ではI, A, P に対応するすべての項目が因子とし てまとまっていたものの, その他の基盤に対応する項 目も同一因子に含まれていた（Table 2)。また，第 1 , 第 2 因子の負荷量の差があまりない項目も複数みられ た。第 1 因子 (寄与率: $19.61 \%$ ) と第 2 因子（寄与率： $14.55 \%)$ の相関は $r=.52$ であった。

最後に, Graham et al. (2011) や, Davies et al. (2014) などで行われたように，確認的因子分析によって複数 のモデルを比較した。その結果,「関連度」,「判断」, 全項目，のいずれでも5 因子モデルの適合度が高かっ た（Table 3)。 $\chi^{2}$ 值の増分の検定 (Nilsson \& Erlandsson, 2015）を行ったところ, 最も小さい 5 因子モデルと, その次に小さい 3 因子モデルの間に有意な差がみられ た (関連度: $\Delta \chi^{2}(7)=42.79, p<.001$; 判断 : $\Delta \chi^{2}(7)=$ $58.53, p<.001$; 全項目 $\left.: \Delta \chi^{2}(7)=36.84, p<.001\right)$ 。ただし, RMSEA に関しては，関連度や全項目を対象とした場 合に 3 因子モデルが 5 因子モデルよりも低い值を示し た。また, CFIが.95 以上, RMSEAが.06 以下という, 広く用いられている適合度の評価基準（Hu \& Bentler, 1999）は，いずれのモデルも満たしていなかった。

イデオロギーとの相関 測定した変数の平均値, 標 準偏差, 相関係数を Table 4 に示す。各道徳基盤とイ デオロギーとの関係は扮抄むね先行研究と一致してお $\eta, \mathrm{I}(r=.19, p<.001), \mathrm{A}(r=.25, p<.001), \mathrm{P}(r=$ $.09, p<.01 ）$ は変化への抵抗と有意な正の相関を示す 一方, $\mathrm{H}(r=.06, n s), \mathrm{F}(r=.01, n s)$ は関連がみられ なかった。平等への選好とは, すべての基盤で有意な 正の相関関係がみられた。

次に，政治的立場とMFQ との関連を検討した（自 らの政治的立場について「わからない」と回答した者 が 214 名いたため, 対象者は 641 名となった)。Haidt （2012）では，H，Fが政治的立場に関連なく全体的に 高い值を示す一方で，I，A，Pはリベラルでは得点が低 く, 保守的になるにつれて $\mathrm{H}, \mathrm{F}$ の得点に近づくこと が指摘されている。本研究でも, I $(r=.18, p<.001)$, $\mathrm{A}(r=.28, p<.001), \mathrm{P}(r=.14, p<.001)$ と政治的立 場との間には有意な正の相関がみられ，各基盤得点が 高くなるほど保守的な政治的立場を選好することが示 された。一方, $\mathrm{H}(r=.04, n s), \mathrm{F}(r=-.05, n s)$ では 関連がみられなかった。東アジアに扔いて $\mathrm{P}$ 得点が やや高くなる傾向について指摘した Graham et al. (2011) と同様に, 本研究でも $\mathrm{P}$ 得点は $\mathrm{H}, \mathrm{F}$ および $\mathrm{I}$, $\mathrm{A}$ 得点の中間付近に位置していた7。

研究 1 では, 日本語版 MFQ の妥当性の検討を行い, 全体として Haidt (2012) の理論と一致する 5 因子モ

\footnotetext{
政治的立場の数值ごとに各道徳基盤の平均值を算出し，図 示したものを電子付録として掲載した。
}

Table 2

Factor Loadings and Communalities from Exploratory Factor Analysis of the Japanese MFQ

\begin{tabular}{|c|c|c|c|}
\hline Foundation & Factor 1 & Factor 2 & Communality \\
\hline \multicolumn{4}{|c|}{ Relevance items } \\
\hline \multicolumn{4}{|l|}{ Harm } \\
\hline 1 Emotionally & .783 & -.152 & .512 \\
\hline 6 Weak & .793 & -.094 & .559 \\
\hline 11 Cruel & .694 & -.058 & .444 \\
\hline \multicolumn{4}{|l|}{ Fairness } \\
\hline 7 Unfairly & .781 & -.116 & .529 \\
\hline 2 Treated & .504 & .043 & .279 \\
\hline 12 Rights & .693 & -.077 & .430 \\
\hline \multicolumn{4}{|l|}{ Ingroup } \\
\hline 13 Loyalty & .263 & .399 & .338 \\
\hline 8 Betray & .439 & .213 & .335 \\
\hline 3 Love country & .032 & .477 & .244 \\
\hline \multicolumn{4}{|l|}{ Authority } \\
\hline 9 Traditions & .094 & .511 & .320 \\
\hline 4 Respect & .019 & .480 & .240 \\
\hline 14 Chaos & .565 & .073 & .368 \\
\hline \multicolumn{4}{|l|}{ Purity } \\
\hline 10 Disgusting & .773 & -.096 & .530 \\
\hline 5 Decency & .557 & .063 & .351 \\
\hline 15 God & .169 & .331 & .196 \\
\hline \multicolumn{4}{|c|}{ Judgement items } \\
\hline
\end{tabular}

\begin{tabular}{llll}
\hline Harm & & & \\
21 Animal & $\mathbf{. 2 2 7}$ & .198 & .137 \\
26 Kill & .033 & $\mathbf{. 2 3 0}$ & .062 \\
$\quad$ Compassion & $\mathbf{. 3 2 6}$ & .269 & .270 \\
Fairness & & & \\
22 Justice & .242 & $\mathbf{. 3 9 7}$ & .315 \\
17 Fairly & $\mathbf{. 2 6 2}$ & .240 & .191 \\
27 Rich & .034 & $\mathbf{. 1 5 9}$ & .032 \\
Ingroup & & & \\
28 Team & -.035 & $\mathbf{. 3 6 0}$ & .118 \\
18 History & -.029 & $\mathbf{. 4 9 2}$ & .228 \\
$\quad$ Family & -.004 & $\mathbf{. 3 0 0}$ & .089 \\
Authority & & & \\
24 Sex roles & -.048 & $\mathbf{. 2 6 1}$ & .057 \\
29 Soldier & -.127 & $\mathbf{. 2 7 7}$ & .056 \\
19 Kid respect & -.182 & $\mathbf{. 6 0 7}$ & .286 \\
Purity & & & \\
20 Harmless disgusting & .173 & $\mathbf{. 3 4 4}$ & .210 \\
25 Unnatural & -.067 & $\mathbf{. 3 6 6}$ & .113 \\
30 Chastity & .000 & $\mathbf{. 3 9 0}$ & .152 \\
\hline
\end{tabular}

Note. Numbers indicated in each item represent the item numbers available at http://www.moralfoundations.org. Oders and expressions of these items are adapted from Graham et al. (2011). 
Table 3

Goodness-of-fit Indices for Structural Models Representing Confirmatory Factor Analyses of the Japanese MFQ

\begin{tabular}{|c|c|c|c|c|c|c|c|}
\hline Model & $\chi^{2}$ & $d f$ & AIC & RMSEA & CFI & GFI & AGFI \\
\hline \multicolumn{8}{|c|}{ Relevance items } \\
\hline 1. Single factor & 854.28 & 90 & 914.28 & .10 & .83 & .86 & .81 \\
\hline 2. Two correlated factors & 778.60 & 89 & 840.60 & .10 & .84 & .87 & .83 \\
\hline 3. Three correlated factors & 645.12 & 87 & 711.12 & .09 & .87 & .90 & .86 \\
\hline 4. Hierarchical model & 741.50 & 84 & 813.50 & .10 & .85 & .88 & .83 \\
\hline 5. Five correlated factors & 602.34 & 80 & 682.34 & .09 & .88 & .91 & .86 \\
\hline \multicolumn{8}{|c|}{ Judgement items } \\
\hline 1. Single factor & 465.90 & 90 & 525.90 & .07 & .75 & .93 & .90 \\
\hline 2. Two correlated factors & 414.59 & 89 & 476.59 & .07 & .78 & .94 & .91 \\
\hline 3. Three correlated factors & 373.96 & 87 & 439.96 & .06 & .81 & .94 & .92 \\
\hline 4. Hierarchical model & 406.44 & 84 & 478.44 & .07 & .78 & .94 & .91 \\
\hline 5. Five correlated factors & 315.43 & 80 & 395.43 & .06 & .84 & .95 & .93 \\
\hline \multicolumn{8}{|c|}{ Full MFQ (all items) } \\
\hline 1. Single factor & 2702.37 & 405 & 2822.37 & .08 & .66 & .77 & .74 \\
\hline 2. Two correlated factors & 2496.39 & 404 & 2618.39 & .08 & .69 & .79 & .76 \\
\hline 3. Three correlated factors & 2308.18 & 402 & 2434.18 & .07 & .72 & .81 & .78 \\
\hline 4. Hierarchical model & 2446.98 & 399 & 2578.98 & .08 & .69 & .80 & .76 \\
\hline 5. Five correlated factors & 2271.34 & 395 & 2411.34 & .08 & .72 & .81 & .78 \\
\hline
\end{tabular}

Note. Model in bold is the best fitting model based on these indices.

Table 4

Mean, Standard Deviation, and Correlation Coefficients of the MFQ Subscales with Other Measures in Study 1

\begin{tabular}{|c|c|c|c|c|c|c|c|c|c|}
\hline & $M$ & $S D$ & 1 & 2 & 3 & 4 & 5 & 6 & 7 \\
\hline 1. Harm $(\alpha=.69)$ & 3.68 & 0.75 & - & & & & & & \\
\hline 2. Fairness $(\alpha=.63)$ & 3.12 & 0.70 & $.67 * *$ & - & & & & & \\
\hline 3. Ingroup $(\alpha=.57)$ & 2.55 & 0.69 & $.42 * *$ & $.45 * *$ & - & & & & \\
\hline 4. Authority $(\alpha=.57)$ & 2.62 & 0.68 & $.30 * *$ & $.35 * *$ & $.62 * *$ & - & & & \\
\hline 5. Purity $(\alpha=.56)$ & 3.00 & 0.71 & $.58 * *$ & $.57 * *$ & $.52 * *$ & $.51 * *$ & - & & \\
\hline 6. Preference for equality & 3.66 & 1.11 & $.36 * *$ & $.35 * *$ & $.21 * *$ & $.11 * *$ & $.28 * *$ & - & \\
\hline 7. Resistance to change & 3.19 & 1.16 & .06 & .01 & $.19 * *$ & $.25 * *$ & $.09 * *$ & .05 & - \\
\hline $\begin{array}{l}\text { 8. Political ideology } \\
\text { Liberal (0) - Conservative (10) }\end{array}$ & 5.37 & 1.98 & .04 & -.05 & $.18 * *$ & $.28 * *$ & $.14 * *$ & -.03 & $.28 * *$ \\
\hline
\end{tabular}

$* * p<.01, * p<.05$

デルの当てはまりが, 他のモデルよりは良いことが示 された。一方で, 探索的因子分析結果の先行研究との 不一致,「判断」項目で測定する各基盤の内的一貫性 の低さ，一般的な評価基準と照らし合わせた場合の 5 因子モデルの適合度の低さ，各基盤間の相関パターン の理論との不一致，なども明らかになった。イデオロ ギーや政治的立場と各基盤の関係性は，おおむね先行 研究と一致する結果が得られた。

\section{研 究 2}

研究 2 では, 研究 1 の参加者の一部を対象に再度 MFQ を測定し，再検査信頼性を検討する。また，イ デオロギーと各道徳基盤との関連について，3 種類の シナリオに対する反応を通して，尺度の妥当性を検討 する。Haidt（2012）によると, リベラルは，上位者 や社会制度によって個人の自由や尊厳が傷つけられた り劦かされたりすることを嫌う。一方で, 保守は, 所 属集団の繁栄に強い関心を持ち, それらの達成のため 
に，時に個人が強い制約を受けることも受容する。こ れらを踏まえ, 研究 2 では, 労働格差（上司は時間的 ゆとりがあるが，その部下は激務をしている）と，在 留資格（不法滞在中の母子のうち，日本語しか話せな い子どもが申請した在留資格が不許可となる）のシナ リオを作成した。労働格差の是正や, 子の在留資格を 認める主張はリベラル的なイデオロギーに関連すると 考えられ，また，そのような反応は道徳基盤における $\mathrm{H}, \mathrm{F}$ と正の関連を示すと予想される。一方で, 社会的 立場の違いによる労働格差はやむなしと考えたり，所 属集団に属さないものに対して厳しい対応（在留資格 を認めない）を示したりする傾向は，保守的なイデオ ロギーに関連すると思われる。そして，そのような傾 向はI, A, P と正の関連を示すと考えられる。

この 2 つのナリオに加えて, 日本においてしばし ばイデオロギーに基づく対立を生じさせる, 戦後の安 全保障㧍よび憲法改正問題に関わるテーマとして国歌 斉唱（公立中学校の卒業式で国歌斉唱を拒否した教員 に校長から厳重注意がなされる）を題材としたシナリ オも作成した。国歌斉唱に対する肯定的な反応は, 愛 国心や国の繁栄のための団結を促す点で保守的なイデ オロギーと関連し，そのような反応は I, A, P と正の 関連を示すと予測される。一方で, 歌詞の内容や, 個 人の思想や信条の自由が脅かされるという点で国歌の 斉唱に否定的な反応をする姿勢はリベラル的なイデオ ロギーと関連すると考えられる。そして，そのような 反応は道德基盤に扔ける $\mathrm{H}, \mathrm{F}$ と関連すると予想され る。

\section{方 法}

参加者 2017 年 7 月に, 研究 1 の分析対象者 855 名 にクラウドソーシングサービスのシステム上で招待 メッセージを送信し，553 名から全項目に対する回答を 得た。回答者に対して, クラウドワークスを経由して 100 円の報酬を支払った。教示文の精読を要する設問で ある Instructional Manipulation Check (IMC: Oppenheimer, Meyvis, \& Davidenko, 2009; 三浦・小林, 2016), および, 研究 1 と同様の DQS 項目に正確に回答した 470 名（女 性 289 名, 男性 181 名; 平均年齢 37.83 歳, $S D=9.58$ ) を最終的な分析対象とした。

手続き 参加者は, MFQ と政治的立場に関する項 目に回答後, ランダムな順序で呈示される 3 種類のす ベてのシナリオを 1 つずつ読み，シナリオごとに用意 された質問項目に回答した。また，シナリオの呈示時 間を 30 秒とし，その間は対応する質問項目に回答す るためのページに移動できないようにして，内容を正 しく読み取るよう促した。

シナリオ 先に述べた通り, 労働格差, 在留資格, 国歌斉唱に関わる 3 パターンのシナリオを作成した。

測定項目（a）日本語版 MFQ（金井, 2013），（b） 政治的立場に加えて，(c) 各シナリオにおいて，イデ オロギーと関連した主張をする項目を作成し，同意で きる程度を問うた。労働格差シナリオでは, 格差の是 正を主張する 2 項目（「労働時間や内容を考えると部 下の給与を引き上げるべきである」,「労働時間や内容 は部下の方が負担が大きいのに, 給与が $1 / 2$ しかない というのは間違っていると思う」; $\alpha=.79)$ と格差を 受け入れることを主張する2 項目（「内容がどうであ れ，部下は上司の指示に従うべきである」,「上司は これまでの経験や実績が認められて今の立場を得たの だから，高い給与を得ていても当然だ」； $\alpha=.66 ） を$ 作成した。在留資格シナリオでは, 在留資格賛成の 3 項目（「子どもは日本語しか話せず，母親の母国での 生活に困難が生じる可能性があることから, 在留特別 許可を認めるべきだ」，「在留特別許可は「日本での 定着性」を条件に与えられるものだが，子どもはこの 条件を十分満たしている」,「入管当局の判断は,「児 童の権利に関する条約」(子どもの権利条約：どのよ うな状況下であっても, 子どもには生きる権利, 守ら れる権利, 育つ権利, 参加する権利があるという, 国 連による規定。日本も批准している)に違反している」; $\alpha=.84$ ) と, 在留資格反対の 3 項目（「このような長 期の不法滞在は, 入国管理の秩序を著しく乱しており, 許されるものではない」,「もっと早く不法滞在であ ることを周囲が通報し，強制退去とするべきだった」， 「このような，長期の不法滞在者を支援する団体は必 要ない」; $\alpha=.79)$, 国歌斉唱シナリオでは, 国歌斉 唱反対の 2 項目（「歌詞の内容が現在の日本社会にそ ぐわないという教員の主張は理解できる」,「過去の戦 争の反省という意味でも，公立学校での国旗掲揚・国 歌斉唱は見直されるべきである」; $\alpha=.74 ）$ と賛成の 2 項目（「国旗揭揚や，国歌斉唱は，日本社会で生活 している以上, すすんで行うべきである」,「公立学校 の式典での国旗掲揚・国歌斉唱は，日本人としての意 識や誇りを持つためにも重要である」; $\alpha=.83 ）$ を作 成した 8 。すべての項目について，「0:まったくそう思 わない」一「6：非常にそう思う」の 7 件法で回答を 求めた。

\section{結果と考察}

再検査信頼性 研究 1 と研究 2 の MFQ の回答デー 夕の相関分析から, 再検査信頼性を検討した。その結

8 これらの項目の他に「教頭や校長による指示は, 個人の思想, 信条の自由を侵害していると思う」,「公立学校の教員は公務員 であるのだから, 起立して国歌斉唱を行うべきだ」も尋ねたが, 項目の内容が国歌斉唱反対・賛成以外に権威に対する認識の要 素も含む可能性があると判断し, 分析からは除外した。なお, これらの項目をそれぞれ国歌斉唱反対, 賛成に加えて分析した 場合も, 結果に大きな違いはみられなかった。 
Table 5

Mean, Standard Deviation, and Correlation Coefficients of the MFQ Subscales with Other Measures in Study 2

\begin{tabular}{|c|c|c|c|c|c|c|c|c|}
\hline \multirow{3}{*}{ Variables } & \multirow{3}{*}{$M$} & \multirow{3}{*}{$S D$} & & $\begin{array}{c}\text { Harm } \\
(\alpha=.74)\end{array}$ & $\begin{array}{l}\text { Fairness } \\
(\alpha=.61)\end{array}$ & $\begin{array}{l}\text { Ingroup } \\
(\alpha=.61)\end{array}$ & $\begin{array}{l}\text { Authority } \\
(\alpha=.67)\end{array}$ & $\begin{array}{l}\text { Purity } \\
(\alpha=.54)\end{array}$ \\
\hline & & & $M$ & 3.68 & 3.16 & 2.43 & 2.55 & 3.01 \\
\hline & & & $S D$ & 0.74 & 0.65 & 0.68 & 0.71 & 0.66 \\
\hline 1. Labor gap-con & 4.69 & 1.20 & & $.16 * *$ & $.24 * *$ & -.02 & -.05 & .05 \\
\hline 2. Labor gap-pro & 2.25 & 1.31 & & -.02 & -.05 & $.21 * *$ & $.27 * *$ & $.10 *$ \\
\hline 3. Special permission to live in Japan-pro & 3.87 & 1.30 & & $.36 * *$ & $.30 * *$ & .03 & -.05 & $.12 *$ \\
\hline 4. Special permission to live in Japan-con & 3.20 & 1.34 & & $-.21 * *$ & $-.13 * *$ & .03 & $.24 * *$ & .03 \\
\hline 5. National anthem-con & 2.83 & 1.38 & & $.18 * *$ & $.17 * *$ & -.08 & $-.12 * *$ & .02 \\
\hline 6. National anthem-pro & 3.13 & 1.43 & & .06 & -.04 & $.36 * *$ & $.32 * *$ & $.20 * *$ \\
\hline 7. Liberal (0) - Conservative (10) & 5.29 & 1.76 & & -.07 & -.07 & $.18 * *$ & $.21 * *$ & .07 \\
\hline
\end{tabular}

Note. Variables 1 through 6 were all measured on a scale from 0 (not at all) to 6 (strongly agree)

$* * p<.01, * p<.05$

果, $\mathrm{H}(r=.65, p<.001), \mathrm{F}(r=.50, p<.001), \mathrm{I} \quad(r=$ $.57, p<.001), \mathrm{A}(r=.59, p<.001), \mathrm{P} \quad(r=.56, p<$ .001) と, いずれも有意な正の相関がみられた。しかし, 一般的な心理尺度で求められる基準（おおむね.70を 超える報告が多く（高本・服部，2015），.50を下回る と不十分であると研究者自身が評価する傾向がある (小塩, 2016)）や, Graham et al.（2011）の結果（5 基 盤で.68-.82) よりはやや低かった。

政治的立場と各基盤の関連 政治的立場と各道徳基 盤得点の相関分析を行ったところ, I $(r=.18, p<$ $.001), \mathrm{A}(r=.21, p<.001)$ と政治的立場との間には 研究 1 と同様に有意な正の相関がみられたが, $\mathrm{P}(r=$ $.07, n s), \mathrm{H}(r=-.07, n s), \mathrm{F}(r=-.07, n s)$ とは関連 がみられなかった。

イデオロギーとの関連３つのシナリオに対する反 応と各道徳基盤との関連を検討した。各変数の平均值, 標準偏差，および相関を Table 5 に示す。まず，シナ リオに対するそれぞれの主張に同意する程度と, 想定 するイデオロギーとの関連を確認した。その結果, 在 留資格賛成 $(r=-.14, p<.001)$, 国歌斉唱反対 $(r=-.28$, $p<.001 ）$ の程度は, 政治的立場と負の, 在留資格反 対 $(r=.19, p<.001)$, 国歌斉唱賛成 $(r=.29, p<.001)$ の程度は正の関連を示した。これらの項目は, イデオ ロギーに基づく操作が適切に行われていたと考えられ る。一方で, 労働格差シナリオでは, いずれの主張も 政治的立場との間に関連がみられなかった（労働格差 の否定 $: r=.01, n s$; 労働格差の受容 $: r=.07, n s)$ 。 ベてのシナリオで, 2 種類の主張の間には有意な負の 相関がみられた（労働格差 $: r=-.53, p<.001$; 在留資 格 : $r=-.20, p<.001$; 国歌斉唱 $: r=-.55, p<.001) 。$

次に，それぞれの主張に同意する程度と，各道徳基 盤との関連を検討するために相関分析を行った。その 結果, 国歌斉唱シナリオ, 在留資格シナリオでは, 予
測と一貫して $\mathrm{H}, \mathrm{F}$ が在留資格賛成, 国歌斉唱反対の 程度と有意な正の相関を示した。I, A, P は, 国歌斉唱 シナリオでは想定通り，賛成の程度とそれぞれが有意 な正の関連をもっていたのに対して, 在留資格シナリ オではAのみが反対の程度と有意な正の関連を示し た。Iは賛成 $(r=.03, n s)$, 反対 $(r=.03, n s)$ のいず れの主張とも関連がみられなかった。また予測とは異 なり, P の高さは在留資格賛成の程度と弱いが有意な 正の相関関係を示した $(r=.12, p<.05)$ 。なお, イデ オロギーの操作が意図通りではなかったものの, 労働 格差シナリオでは予測と一貫して $\mathrm{H}, \mathrm{F}$ が格差の是正 を主張する意見と, I, A, P が格差を受け入れる程度と, それぞれ有意な正の関連をもっていた。

\section{総合考察}

本研究では, Haidt らによる道徳基盤理論（Haidt, 2012; Haidt \& Joseph, 2004, 2007）に基づき，5つの道 徳基盤と個人との関わりの強さを測定する尺度である MFQ（Graham et al., 2011）の日本語版（金井, 2013） の妥当性, 信頼性を 2 つ研究を通して検証した。先 行研究との類似点としては，（a）探索的因子分析結果 の全体的な構造, (b) 確認的因子分析における 5 因子 モデルの相対的な優位性, (c) 政治的態度やイデオロ ギーとの関係などが挙げられる。特に,リベラルおよ び保守的な主張との相関パターンが, H, F と I, A, P とで異なり, Haidt (2012) の理論と一致する傾向が研 究 2 で多く示された点は興味深い。一方で, 相違点も 無視できない。例えば, H, F と I, A, P 基盤は正の相 関を示し，特に F と P はすべての基盤と有意な正の 相関関係を示した。また,「関連度」と「判断」の相 関分析（Table 1), 探索的因子分析（Table 2）の結果 にみられるような妥当性の低さや, 先行研究と異なる 結果が示された部分もあった。確認的因子分析におい 
ても，適合度指標によっては 3 因子モデルの当てはま りが良いという結果もみられた。全体として Graham et al. (2011) ほど明確には 5つの基盤間の差異を検出 することはできなかったと言える。その理由の 1 つと して, I, A, P の得点が Graham et al. (2011) に比べてや や高く、ばらつきも小さいことがあるかもしれない。

5 つの道徳基盤のうち, $\mathrm{P}$ は上述した平均値の高さ やばらつきの小ささが特に顕著であった。全項目を用 いた場合の信頼性係数が他の基盤よりも低く, 予測と 一貫しない結果が他の基盤と比較して多く得られた。 また, 研究 2 では, 保守的な政治的立場との関連もみ られなかった。イデオロギーとの関連性についても, 在留資格に賛成する主張と正の関連が示された。Pは 神との関係性に加え, 嫌悪感情や貞節に関わる内容が 1 つの基盤として仮定されている。日本は特定の信仰 をもたない人が多く（西，2009），この点については 欧米圈の文化と異なる。一方で, 宗教的なイベントへ の参加や，そのような場における不浄の忌避，女人禁 制のルールなどは信仰心とは独立して受け入れられて いる。こうした点を考えると，神との関係性に関する 文化差，およびそれと嫌悪感情や貞節に関わる個人の 価值観の違いとの関連を含めて, Pの構造を明らかに するような研究を進めるべきである。

研究 2 の労働格差シナリオは, 回答者の政治的立場 とは関連がみられなかったが，それぞれの主張に対す る反応と道徳基盤尺度との間には予測と一致する関連 がみられた。政治的立場との間に関連がみられなかっ た原因の 1 つとしては, 保守的な立場をとる人々が, 社会システムや上下関係の維持を重視すると同時に, 比例配分や因果応報のような公正さにも関心をもつか らかもしれない(Haidt, 2012)。労働格差シナリオには, 上下関係に関わる問題と同時に，比例配分に関わる内 容も含まれていたため, 結果として政治的立場との関 連が希薄化された可能性がある。

\section{日本語版 MFQ の使用にあたって注意すべき点}

本研究の結果を踏まえた, 日本語版 MFQ の使用方 法に関する指針を述べる。オリジナルの 30 項目で構 成される 5 因子モデルは, 先行研究で検討された他の どのモデルと比べても相対的な当てはまりは良かっ た。適合度指標の值は，広く用いられている評価基準 に満たないものの, スウェーデン語版（Nilsson＆ Erlandsson, 2015） やハングル語版 (Kim et al., 2012) と比べて著しく低いわけではない。また, Graham et al. (2011) も，様々な場面を対象とした測定を行うこ とを優先して尺度を構成しているために内的一貫性が 低くなるのはやむを得ないと主張している。どこまで 許容するのかという問題は残るが，日本語版のみが妥 当性に大きな問題があるということはないだろう。た だし，P 基盤は特に信頼性係数が低く，政治的立場と
の関倸性のように, 研究 1 と 2 で一貫しない結果もみ られた。P 基盤は Haidt (2012) が想定するよりも複雑 な構造をしている可能性や, 文化による差が存在する 可能性もある。得られる結果の解釈には留意する必要 がある。

測定の妥当性を重視する場合の方法として, H, F を 含む個人志向, I, A, P を含む連帯志向の 2 因子に基づ く検討が挙げられる。スウェーデン, 韓国, トルコの 研究でも, 2 因子に基づく検討の方が, 信頼性が高く なる可能性について述べられている。例えばNilsson \& Erlandsson（2015）では，2因子に基づく検討で，政 治的立場との関連性に扔いて Haidt（2012）の主張と 一貫した結果が得られている。本研究でも, 研究 1 の データを用いて個人志向, 連帯志向の項目の信頼性係 数を算出したところ, 前者が $\alpha=.80$, 後者で $\alpha=.79$ と, 比較的高い值を示していた。内的一貫性をさらに高め るために探索的因子分析の繰り返しによる項目選択を 行い，新たな尺度を作成するという方向性も考えられ よう9。

なお，文化による思考様式の差異を説明する概念と して個人主義／集団主義があり，道徳基盤理論におけ る個人志向／連帯志向との類似性や差異については議 論があるかもしれない。文化による思考様式は人の基 本的な価值観や道徳判断に影響する（Miller, Bersoff, \& Harwood, 1990)。個人主義／集団主義の枠組みが当 てはまらないとされるトルコにおいて MFQ の妥当性 を検討した研究では, 個人主義的な思考様式をプライ ミングすると $\mathrm{H}$ 基盤が, 集団主義的な思考様式の場 合は I 基盤の得点が高くなることが示された（Yilmaz et al., 2016)。このことからも文化的な思考スタイルや 価値観が道徳基盤と関連することは間違いないだろ う。一方で, 両者の理論的背景や研究を通して明らか にしたいことは大きく異なる。両者の関係性を精緻化 するには, 自己報告式の MFQ のみではなく, 生理指 標や潜在指標を用いた統合的な知見の整理が重要にな るだろう。

本研究では道徳基盤に 5 因子構造を仮定する日本語 版 MFQ の妥当性及び信頼性について検討した。道徳 基盤とイデオロギーには一定の関連が示されたが, 同 時に, 5 因子構造については妥当性の低さや特定の基 盤の測定の信頼性に関する問題が明らかになった。今 後は, これらの結果を踏まえた上で, 研究目的や関連 性を検討する変数との組み合わせを考慮した使用が望 まれる。

この方向性に従って項目選定を行い, 20 項目で構成した個 人志向, 連帯志向の尺度案, および研究 1,2 で測定した他の変 数との相関分析の結果を電子付録として掲載した。 


\section{利益相反の開示について}

本論文に関して, 開示すべき利益相反関連事項はな w。

\section{引用文献}

Bowman, N. (2010). German translation of the Moral Foundations Questionnaire: Some preliminary results. Retrieved from http://onmediatheory.blogspot. jp/2010/07/german-translation-of-moral-foundations. html (January 10, 2017)

Davies, C. L., Sibley, C. G., \& Liu, J. H. (2014). Confirmatory factor analysis of the Moral Foundations Questionnaire: Independent scale validation in a New Zealand sample. Social Psychology, 45, 431-436.

Graham, J., Haidt, J., \& Nosek, B. A. (2009). Liberals and conservatives rely on different sets of moral foundations. Journal of Personality and Social Psychology, 96, 1029-1046.

Graham, J., Nosek, B. A., Haidt, J., Iyer, R., Koleva, S., \& Ditto, P. H. (2011). Mapping the moral domain. Journal of Personality and Social Psychology, 101, $366-385$

Haidt, J. (2012). The righteous mind: Why good people are divided by politics and religion. New York: Pantheon Books.

Haidt, J., \& Graham, J. (2007). When morality opposes justice: Conservatives have moral intuitions that liberals may not recognize. Social Justice Research, 20, 98116.

Haidt, J., Graham, J., \& Joseph, C. (2009). Above and below left-right: Ideological narratives and moral foundations. Psychological Inquiry, 20, 110-119.

Haidt, J., \& Joseph, C. (2004). Intuitive ethics: How innately prepared intuitions generate culturally variable virtues. Daedalus, 133(4), 55-66.

Haidt, J., \& Joseph, C. (2007). The moral mind: How 5 sets of innate moral intuitions guide the development of many culture-specific virtues, and perhaps even modules. In P. Carruthers, S. Laurence, \& S. Stich (Eds.), The innate mind (Vol. 3, pp. 367-391). New York: Oxford University Press.

Haidt, J., Koller, S., \& Dias, M. (1993). Affect, culture, and morality, or is it wrong to eat your dog? Journal of Personality and Social Psychology, 65, 613-628.

Hu, L., \& Bentler, P. M. (1999). Cutoff criteria for fit indexes in covariance structure analysis: Conventional criteria versus new alternatives. Structural Equation Modeling, 6, 1-55.

Iyer, R., Koleva, S., Graham, J., Ditto, P., \& Haidt, J. (2012). Understanding libertarian morality: The psychological dispositions of self-identified libertarians. PLoS ONE, 7(8), e42366. https://doi.org/10.1371/ journal.pone.0042366

Jost, J. T., Napier, J. L., Thorisdottir, H., Gosling, S. D., Palfai, T. P., \& Ostafin, B. (2007). Are needs to man- age uncertainty and threat associated with political conservatism or ideological extremity? Personality and Social Psychology Bulletin, 33, 989-1007.

Kanai, R. (2012). MFQ Translations (Japanese). Retrieved from https://docs.google.com/spreadsheets/d/1UflzHkc8g5ohW MIKGzbrGH5bIPiJoWcSvfuq7OsoYc/edit\#gid=39 (January 10, 2017)

金井良太 (2013)。脳に刻まれたモラルの起源一人 はなぜ善を求めるのか一岩波書店

唐沢 穣 (2013). 社会心理学における道徳判断研究の 現状 社会と倫理, 28,85-99.

Kim, K. R., Kang, J., \& Yun, S. (2012). Moral intuitions and political orientation: Similarities and differences between Korea and the United States. Psychological Reports, 111, 173-185.

Kohlberg, L. (1968). The child as a moral philosopher. Psychology Today, 2, 24-30.

小杉考司 (2013)。現代学生の規範意識と態度 (3) 山口大学教育学部研究論叢第 3 部, 62, 119-123.

Miller, J. G., Bersoff, D. M., \& Harwood, R. L. (1990). Perceptions of social responsibilities in India and the United States: Moral imperatives or personal decisions? Journal of Personality and Social Psychology, 58, 33-47.

三浦麻子・小林哲郎（2016）。オンライン調査におけ る努力の最小限化 (Satisfice) を検出する技法 一大学生サンプルを用いた検討——社会心理 学研究, 32, 123-132.

村山 綾・三浦 麻子 (2017). 日本語版 Moral Foundation Questionnaire の妥当性の検討 日本グループダイ ナミックス学会第 64 回大会発表論文集, 63-64.

Nilsson, A., \& Erlandsson, A. (2015). The Moral Foundations taxonomy: Structural validity and relation to political ideology in Sweden. Personality and Individual Differences, 76, 28-32.

西久美子 (2009).「宗教的なもの」にひかれる日本人 —ISSP 国際比較調查（宗教）から——放送 研究と調査, 5 月号, 66-81. Retrieved from http:// www.nhk.or.jp/bunken/summary/research/ report/2009_05/090505.pdf（2017 年 1 月 10 日）

Oppenheimer, D. M., Meyvis, T., \& Davidenko, N. (2009). Instructional manipulation checks: Detecting satisficing to increase statistical power. Journal of Experimental Social Psychology, 45, 867-872.

小塩真司（2016）。心理尺度構成における再検査信頼 性係数の評価一「心理学研究」に揭載された文 献のメ夕分析から—— 心理学評論, 59, 68-83.

Piaget, J. (1965). The moral judgement of the child. Glencoe, IL: Free Press. (Original work published 1932, London: Routledge \& Kegan Paul.)

坂本 剛 · 野波 寛・大友 章司 - 田代 豊 (2014). 政策 決定の権利証人過程における道徳判断の影響— WWG II での正統性判断と道徳基盤との関連— 日本社会心理学会第 55 回大会発表論文集, 362 .

Shweder, R., \& Haidt, J. (1993). The future of moral psychology: Truth, intuition, and the pluralist way. Psychological Science, 4, 360-365.

Shweder, R. A., Much, N. C., Mahapatra, M., \& Park, L. 
(1997). The "big three" of morality (autonomy, community, and divinity), and the "big three" explanations of suffering. In A. Brandt \& P. Rozin (Eds.), Morality and health (pp. 119-169). New York: Routledge.

高本真寛・服部 環（2015）。国内の心理尺度作成論文 における信頼性係数の利用動向 心理学評論, $58,220-235$.
Yilmaz, O., Harma, M., Bahçekapili, H. G., \& Cesur, S. (2016). Validation of the Moral Foundations Questionnaire in Turkey and its relation to cultural schemas of individualism and collectivism. Personality and Individual Differences, 99, 149-154.

- 2018. 1.22 受稿, 2019.1.26 受理 